\title{
A Poem About Not Writing Poems
}

\section{Meena Kandasamy*}

Address

*Correspondence: @meenakandasamy

These days I write nothing

except my eyes, why share

my drugs of angst or absolute

godlessness when the price,

they have said, will have to be

paid in blood, why speak of meat

or beef, when the aftertaste of talk

Is not just a threat of televised gangrape,

but a village gathering to slaughter a man,

Authors. This poem is issued under the terms of the Creative Commons Attribution NonCommercial Share Alike License, which permits use and redistribution of the work provided that the original author and source are credited, the work is not used for commercial purposes and that any derivative works are made available under the same license terms.

again, why force fit my words to capture

the state, its terror, this state of terror

when friends who planned to read marx

had prison cells waiting for them, so why

risk, why run for dear life, why rage at all?

"What cannot be said must be suppressed."

"Why show the scar on your thigh to strangers?" -

Lessons I once learnt in my bedroom

are lessons for life.

So, in lamp black, I only write my eyes

in the ritual way some Tamil women

draw a kolam each day, rice flour

out sparkling the early morning sun, 
rigid dots anchoring snaking lines, all discipline

a deception to hide the wildness, all symmetry

an excuse for keeping count.

Watch a woman's hands

dance an intricate design,

learn that it's her desire

that she is pouring out

on her doorstep. Like her,

this woman in the mirror

is a woman who pretends

to know her place. Each

night, she washes her eyes,

unwraps her word-wounds,

takes them to bed. At daybreak

she applies a fresh dressing.

Meena Kandasamy is a poet, fiction writer, translator and activist who lives in Chennai and London. She has published two collections of poetry, Touch and Ms. Militancy, and the critically acclaimed novel The Gypsy Goddess. Her newly published novel, When I Hit You: Or, The Portrait of the Writer as a Young Wife (Atlantic Books, May 2017), explores the theme of domestic violence and marital rape.

\section{To cite this poem:}

Kandasamy, M. (2017). A Poem About Not Writing Poems. Feminist Dissent, (2), 83-84. Retrieved from:

http://journals.warwick.ac.uk/index.php/feministdissent/article/view/16/17 $\underline{2}$ 